\title{
DEACTIVATION BY CARBON OF IRON CATAL,YSTS FOR INDIRECT LIQUEFACTION
}

\author{
Quarterly Technical Progress Repon \\ For Period September 16, 1989 to December 15, 1989
}

\author{
Calvin $\mathrm{H}$. Bartholomew \\ Brigham Young University \\ Provo, Utah 84602
}

Date Published - October 11, 1990

\section{PREPARED FOR THE UNITED STATES DEPARTMENT OF ENERGY}

Under Contract No. DE-FG22-86PC90533

\section{"US/DOE fratent Clearance is not required prior to the publication of this documerit"}

\section{DISCLAIMER}

\footnotetext{
This report was prepared as an account of work sponsored by an agency of the United States Government. Neither the United States Government nor any agency thereof, nar any of their employees, makes any warranty, express or implied, or assumes any legal liability or responsibility for the accuracy, completeness, or usefulness of any information, apparatus, product, or process disclosed, or represents that its use would not infringe privately owned rights. Reference herein to any specific commercial product, process, or service by trade name, trademark, manufacturer, or otherwise does not necessarily constitute or imply its endorsement, recommendation, or favoring by the United States Government or any agency thereof. The views and opinions of authors expressed herein do not necessarily state or reflect those of the United States fover:- ment or any agency thereof.
} 


\section{DISCLAIMER}

This report was prepared as an account of work sponsored by the United States Goverriment. Neither the United States nor the United States DOE, nor ary of their employees nor any of their contractors, subcontractors, or their employees, makes any warranty, express or implied, or assumes any legal liability or responsibility for the accuracy, completeness, or usefulness of any information, apparatus, product or process disclosed, or represents that its use would not infringe privately owned rights. 


\section{FORWARD}

This report summarizes technical progress during the thirteenth quarter (September 16, 1989 to December 15, 1989) of a three-year study conducted fo; the Depariment of Energy (DOE) under Contract No. DE-FG22-86PC90533. The principal investigator for this work was Dr. Calvin H. Bartholomew; Dr. Sayeed Akhtar was the technical representative for DOE.

Scott Eliason, Ph.D. candidate, contributed to the technical accomplishments and to this report. Dr. Bartholomew was the principal author. 


\section{TABLE OF CONTENTS}

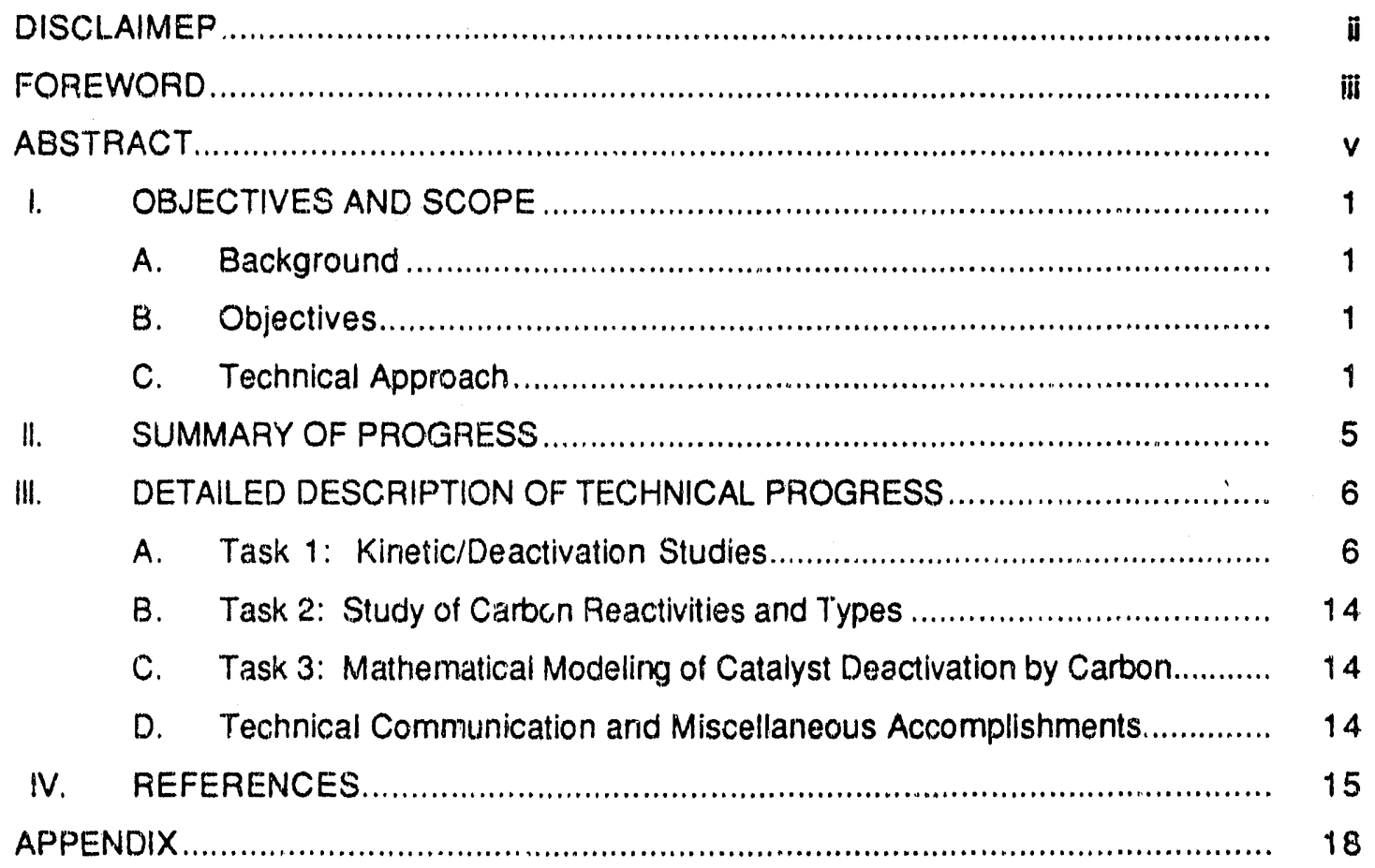




\begin{abstract}
During the thirteenth quarter design of software for a computer-automated reactor system to be used in the kinetic and deactivation studies was continued. Further progress was made towards the completion of the control language, control routines, and software for operating this system. Progress was also made on the testing of the system hardware and software. $\mathrm{H}_{2}$ chemisorption capacities and activity selectivity data were also measured for three iron catalysts promoted with $1 \%$ alumina. The PI, one associate and several students attended Advances in Catalytic Chemistry IV held October 1-6 at Snowbird, Utah where the PI presented a paper.
\end{abstract}




\section{OBJECTIVES AND SCOPE}

\section{A. Background}

Although promoted cobalt and iron catalysts for Fischer-Tropsch (FT) synthesis [1] of gasuline feedstock were first developed more than three decades ago, a major technical problem still limiting the commercial use of these catalysts today is carbon deactivation. Carbon deactivation is especially severe in processes that directly use synthesis gas with an $\mathrm{H}_{2}: \mathrm{CO}$ ratio of approximately $1: 2$ or less. Because these conditions are thermodynamically and kinetically favorable for carbon formation, rapid deactivation and physical disintegration of the catalyst are possible. Indeed, carbon formation is the major cause for loss of catalyst activity in the only presently commercial FT process in South Africa [1]. Thus, there is considerable motivation for understanding the fundamental mechanisms of carbon deactivation in order to find means of mitigating these problems. Models and/or data for predicting rate of carbon formation and its effects are needed so that the deleterious effects on catalysts and processes can be minimized. Data are especially needed for $\mathrm{Fe} / \mathrm{K}$ catalysts because of their clear cost advantage and commercial significance.

\section{B. Objectives}

This report describes resent progress in a fundamental, three-year investigation of carbon formation and its effects on the activity and selectivity of promoted iron catalysts for FT synthesis, the objectives of which are:

1. Determine rates and mechanisms of carbon deactivation of unsupported $\mathrm{Fe}$ and $\mathrm{Fe} / \mathrm{K}$ catalysts auring $\mathrm{CO}$ hydrogenation over a range of $\mathrm{CO}$ concentrations, $\mathrm{CO}: \mathrm{H}_{2}$ ratios, and temperatures.

2. Model the rates of deactivation of the same catalysts in fixed-bed reactors.

\section{Technical Approach}

To accomplish the above objectives, the project will be divided into the following tasks:

1. Determine the kinetics of reaction and of carbon deactivation during $\mathrm{CO}$ hydrogenation on $\mathrm{Fe}$ and $\mathrm{Fe} / \mathrm{K}$ catalysts coated on monolith bodies.

2. Determine the reactivities and types of carbon deposited during reaction on the same catalysts from temperature-programmed-surface-reaction spectroscopy (TPSR) and transmission electron microscopy (TEM). Determine the types of iron carbides formed at various temperatures and $\mathrm{H}_{2} / \mathrm{CO}$ ratios using $x$-ray diffraction and Moessbauer spectroscopy.

3. Using a reaction model for FT synthesis developed in this laboratory, the kinetics of reaction and deactivation measured in Task 1 , and models of fixed-bed reactors from 
other workers, develop mathematical deactivation models which include heat and mass transport contributions for FT synthesis in packed-bed reactors.

The approach for each of these areas of study is described below:

Task 1: Kinetic/Deactivation Studles. While some kinetic data are available for $\mathrm{CO}$ hydrogenation on $\mathrm{Fe} / \mathrm{K}[2-4]$, it is proposed that additional data be obtained with catalysts prepared in this study to confirm the previous work and to extend the range of experimental conditions, e.g. femperature and $\mathrm{CO}: \mathrm{H}_{2}$ ratio. Wash-coated monolithic catalysts will be used to minimize the effects of pore diffusion on the rate of reaction $[5,6]$. Iron catalysts used in the kinetic studies will be prepared by wash-coating Celcor (Corning Glass Works) monoliths $(2.5 \mathrm{~cm}$ diam. by $1 \mathrm{~cm}$ long) with aqueous slurries containing previously reduced and passivated $\mathrm{Fe}$ or Fe/K catalysts. Washcoating procedures have been developed in this laboratory [5-8] which enable thin layers of either supported or unsupported catalysts to be deposited on the walls of monolith channels. These washcoated monolithic catalysts are ideal for kinetic studies because of their low pressure drops and high effectiveness factors $[5,6]$.

$\mathrm{Fe}$ and $\mathrm{Fe} / \mathrm{K}$ catalysts will be prepared according to procedures recently veveloped in our lab $(9,10):(1)$ decomposition of iron nitrate (or iron and potassium nitrates) at $200^{\circ} \mathrm{C}$ in inert gas followed by reduction and/or (2) impregnation of the dehydroxylated alumina support with Fe pentacarbony/pentane followed by drying and reduction. The latter technique results in Fe/alumina catalysts of high dispersion and extent of reduction. Thus, this latter technique could be used to some advantage in the preparation of Fe/alumina/monolith catalysts for the kinetic/deactivation studies. After drying, the catalysts will be reduced in flowing hydrogen at $400-450^{\circ} \mathrm{C}$, using an established heating schedule that maximizes surface area $[10,11]$. Hydrogen uptakes of the reduced catalysts will then be measured so that reaction rates can he compared on the basis of catalytic surface area. These measurements will also be based on techniques recently developed in this laboratory $[9,11]$. Data obtained in this laboratory $[9,10,12]$ indicate that the activities and selectivities of $\mathrm{Fe}$ and $\mathrm{Fe} / \mathrm{K}$ catalysts piepared by our techniques have catalytic properties typical of iron FT catalysts.

Reaction kinetic and deactivation studies will be carried out using a Berty internal recycle reactor system previously described $[5,13]$. The Berty CSTR reactor has ihe advantages of (i) gradientless operation with respect to temperature and reactant concentrations, and (ii) the capability of adjusting the stirring speed to eliminate effects of external mass transport. The combination of the Berty reactor and wash-coated monolithic catalysts will ensure the collection of intrinsic surface reaction rates in the absence of pore-diffusional and external film diffusional disguises $[5,13]$. The use of the Berty reactor also enables deactivation kinetics to be measured directly and unambiguously for each given set of conditions $[7,14]$. As part of this task the Beriy Reactor System will be computer automated and the analysis will be augmented by the addition of a new H.P. 5890 chromatograph slaved to a micro computer. 
Reaction kinetics will be obtained by measuring $C O$ conversion over a range of temperatures and reactant concentrations, e.g. $180-250^{\circ} \mathrm{C}, \mathrm{PCO}=10-50 \mathrm{kPa}, \mathrm{PH}_{2}=10-50 \mathrm{kPa}$, and $\mathrm{H}_{2}: \mathrm{CO}=1.1-3.1$. To ensure the collection of intrinsic kinetic data in the absence of deactivation phenomena, the reaciant gasses and argon diluent will be carefully purified of oxygen, sulfur compounds, and iron pentacarbonyl. Deactivation effects due to carbon will be avoided during kinetic measurements by careful choice of operating conditions and by periodically treating the catalyst in pure hydrogen just prior to changing gas, composition and temperature. Kinetic data will be obtained over a period nf 24 hours at each condition so that both initial and steady-state rates and product distributions are obtained. Product distributions will be measured on-line using heated lines to carry the products to a chromatograph equipped with glass capillary and Chromosorb 102 columns connected to flame ionization and thermal conductivity detectors, respectively, as described previously [15]. The study of $\mathrm{Fe}$ and $\mathrm{Fe} / \mathrm{K}$ catalysts will enable the effects of potassium on the reaction kinetics to be determined.

Deactivation kinetics due to carbon formation will be obtained by measuring $c 0$ conversion and product distribution as a function of time for 24-48 hours at a given set of reaction conditions. Temperatures and reactant concentrations will be varied from run to run, e.g. $250-350^{\circ} \mathrm{C} ; \mathrm{PCO}=10-50$ $\mathrm{kPa}$; and $\mathrm{H}_{2}: \mathrm{CO}=0.5-2.0$. Again the study of both $\mathrm{Fe}$ and $\mathrm{Fe} / \mathrm{K}$ catalysts will permit effects of potassium on the kinetics of deactivation to be determined.

Task 2: Study of Carbon reactivities and Types. The reactivities of carbon species deposited during $\mathrm{CO}$ hydrogenation on $\mathrm{Fe}$ and $\mathrm{Fe} / \mathrm{K}$ catalysts will be determines' using temperatureprogrammed-surface-reaction spectroscopy (TPSR) with hydrogen $[7,16]$. The data will be obtained using a TPD system featuring a UTI-100C quadrupole mass spectrometer and programmable peak selector [17]. The peak selector enables up to 9 different peaks to be selected simultaneously and will facilitate analysis of methane and $\mathrm{C}_{2+}$ hydrocarbons during TPSR of the carbon-deactivated catalysts with hydrogen.

Catalysts will be pretreated in synthesis gas $\left(\mathrm{H}_{2}: \mathrm{CO}=0.5\right.$ to 2.0) at various reaction temperatures (e.g. 250 to $350^{\circ} \mathrm{C}$ ) over a period of $16-24$ hours, cooled in He carrier gas to $25^{\circ} \mathrm{C}$, and then reacted with $\mathrm{H}_{2}\left(10 \% \mathrm{H}_{2}\right.$ in $\mathrm{He}$ or $\left.\mathrm{Ar}\right)$ while increasir.y the temperature of the sample at a linear rate of $30^{\circ} \mathrm{C} / \mathrm{min}$. The use of small, powdered samples (50-100 mg; 80-100 mesh) and low carrier gas ílow rates $(20-40 \mathrm{~cm} 3 / \mathrm{min})$ will ensure the absence of intra- and interparticle concentration gradients [17-21] These conditions have been shown in previous TPD studies conducted in this laboratory [17-19] to be optimum for minimizing pore diffusion effects, sample measurement lag times, and concentration gradients [20,21]. Previous studies of carbon-deactivated catalysts with TPSR $[7,16,22]$ have enabled identification of different carbon species having a range of reactivities. Again, it is important to investigate both $\mathrm{Fe}$ and $\mathrm{Fe} / \mathrm{K}$ catalysts since Dwyer [23] found evidence of different forms of carbon on clean iron and potassiumcovered iron surfaces. 
Different forms of carbon deposited during CO hydrogenation on iron catalysts will be identified by submitting samples from the deactivation rate studies for examination by transmission electron microscopy (TEM). TEM has been used in several previous investigations in this laboratory to identify different forms of carbon--particularly vermicular (filamentous) carbons [24-26]. By submitting samples tested at various temperatures, it will be possible to determine at which temperature vermicular carbon formation occurs.

The role of iron carbides in deactivation during $\mathrm{CO}$ hydrogenation will be determined by analyzing spent catalysts from the deactivation runs by $x$-ray diffraction and Moessbauer spectroscopy. Moessbauer spectroscopy has alread, proven itself as a useful tool for identifying various iron carbides formed during CO hydrogenation [27-29]. It will be interesting to determine if certain carbides are associated with the more severe conditions of carbon deactivation, i.e. high temperature and low $\mathrm{H}_{2}: \mathrm{CO}$ ratio and how potassium afiects carbide formation.

Task 3: Mathematical Modeling of Catalyst Deactlvation by Carbon. The development of a chemical mathematical model for deactivation of iron catalysts during Fischer-Tropsch synthesis will follow an approach similar to that used previously in this laboratory to model methanation in fixed beds $[5,30,31]$. The one-dimensional, quasi-steady-state model will feature simultaneous solution of (i) the rate equations for the main reaction and for deactivation $[14,32,33]$. The kinetics for the main reaction will be calculated according to the model recently developed by Rankin and Bartholomew [34] and will be based on the dissociation of adsorbed carbon monoxide, subsequent hydrogenation of the surface carbide [7,16, 35-37], and provision for the Anderson-Schulz-Flory polymerization mechanism [38-41]. This reaction model enables the calculation of intrinsic rate constants for initiation, termination, and propagation, as well as values for the polymerization probability. This reaction model also has a provision which accounts for the formation of olefins and oxygenates in the case of the iron catalysts. In addition, the kinetics of the water-gas-shift reaction [42] will be added. The effects of pore diffusion resistance will not be considered at this point. The coupled differential equations will be solved by finite difference [43]. Model predictions will be closely compared with experimental results obtained at high conversions in the CSTR Berty reactor. The model will be used initially to predic ' rtalytic activity, selectivity, reactant concentration, and temperature as functions of time and position in the fixed-bed reactor. 


\section{SUMMARY OF PROGRESS}

Progress can be most efficiently summarized by task:

\section{A. Task 1: KInetic/Deactivation Studies}

During the thirteenth quarter design of software for a computer-automated reactor system to be used in the kinetic and deactivation studies was continued. Further progress was made towards the completion of the control language, control routines, and software for operating this system. Progress was also made on the operating manual and testing of the system hardware and software.

Hydrogen adsorption capacities and activity/selectivity properties were measured over a range of temperatures and reactant concentrations for three alumina-promoted iron catalysts ( $\mathrm{Fe}$ A-203, -204, and 2u5). Activities and selectivities were also measured as a function of time. From these data it is evident that activity and selectivity properties reach steady-state conditions after about 20 hours. Deactivation is observable at higher reaction temperatures, especially at $230^{\circ} \mathrm{C}$; during 72 hours of reaction at $230^{\circ} \mathrm{C}, 1 \mathrm{~atm}$, and $\mathrm{H}_{2} / \mathrm{CO}=2$, normalized activity decreases $75 \%$.

\section{B. Task 2: Study of Carbon Reactivitles and Types}

No experiments are scheduled for this Task until Fall 1990, although literature study is being conducted.

\section{Task 3: Mathematical Modeling of Catalyst Deactivation by Carbon} This task is scheduled to begin in Winter 1991.

\section{Task 4: Technical Communication and Miscellaneous Accomplishments}

The PI, Calvin $\mathrm{H}$. Bartholomew, his associate Williarn C. Hecker, and several students aftended Advances in Catalytic Chemistry held October 1-6 at Snowbird, Utah. The PI presented an invited paper dealing with "Effects of Structure on CO Hydrogenation on Alumina-supported Cobalt and Iron." 


\section{DETAILED DESCRIPTION OF TECHNICAL. PROGRESS}

\section{A. Task 1: Kinetic/Deactivation Studles}

\section{Construction and Testing of the Automated Berty Reaction System.}

During the thirteenth quarter design of software for a computer-automated reactor system to be used in the kinetic and deactivation studies was continued. Further progress was made towards the completion of the control language, control routines, and software for operating this system. Progress was also made ori tesing of the system hardware and software. Pressure and flow tests of the hardware were conducted, and defective flow meters, solenoids, and wiring were repaired. Some bugs in the control software were found and corrected.

\section{Kinetic Studies.}

Hydrogen adsorption and $\mathrm{CO}$ hydrogenation kinetic studies were conducted on three different samples of iron catalyst promoted with $1 \%$ alumina from the same batch. The results are reported by catalyst below.

Results for Fe-A-203. Hydrogen chemisorption uptakes were measured on the fresh catalyst using two different precision pressure gages. Chemisorptions 1 through 5 were performed with one gage and 6 through 11 were performed with the other. The reason for the change was a leak in the system causing unstable pressures when performing the chemisorptions. It was thought that there was a leak in the Bouri'on tube from the pressure side to the reference side. The results from the first set of chemisorptions gave $30.0 \pm 4.2 \mu$ moles $\mathrm{H}_{2}$ uptake per gram of catalyst (with $95 \%$ confidence) and ranging from 26 to $35 \mu$ moles $/ g$. The second set, which still appeared to have the same leak problem, gave $54.6 \pm 12.3 \mu$ moles $/ g$ with a range from 36 to 70 $\mu$ moles $/ g$. These numbers compare with previous data obtained on catalyst Fe-A-201 which averaged $37.0 \mu$ moles $/ g$. Because of the problems associated with these later chemisorptions the previous value of 37.0 is used in activity calculations. It was later found out that part of the prot lem was that it takes a significant amount of time to evacuate the reference side of the Bourdon tube because of the relatively large volume $(80 \mathrm{cc})$ and small diameter channel to the vacuum apparatus. Some additional leakage may have occurred from some Swagelock connectors at the gage.

Reactions were run on catalyst Fe-A-203 following the chemisorption measurements at temperatures ranging from 200 to $230^{\circ} \mathrm{C}$ and at $\mathrm{H}_{2} / \mathrm{CO}$ ratios from $3 / 1$ to $1 / 1$. The schedule previously set up in which the catalyst was reacted at $200^{\circ} \mathrm{C}$ 
for 20-24 hours followed by reactions at successive $10^{\circ}$ incrernents in temperature for 12 hours was not adhered to strictly. This previous schedule was chosen because the catalyst appeared to reach a steady-state condition after about 24 hours on stream. However, because of deacivation at higher temperatures the schedule was changed. Table $i$ shows the reaction sequence and conditions for the runs performed on this catalyst. Shown are the intended $\mathrm{H}_{2} / \mathrm{CO}$ ratios, the actual flows of $\mathrm{H}_{2}, \mathrm{CO}$ and $\mathrm{He}$ (in $\mathrm{cc} / \mathrm{min}$ ), time of reaction at the given temperature, and sample times. Helium was used as diluent in some cases so that reaction results could be obtained at constant reactant partial pressures of $\mathrm{H}_{2}$ or $\mathrm{CO}$ while varying the $\mathrm{H}_{2} / \mathrm{CO}$ ratio. However, addition of a reactant line for $\mathrm{He}$ increased the instability of the reactant flows and thus some of the flow settings are not precisely at the desired conditions. The catalyst was rereduced at about $400^{\circ} \mathrm{C}$ between each reaction set to minimize deviations due to deactivation. Finally the catalyst was operated at $230^{\circ} \mathrm{C}$ and $\mathrm{H}_{2} / \mathrm{CO}=1.5$ for 67 hours to observe effects of deactivation.

The most reliable results are from $3 / 1(B)$ and the deactivation run (see Table 1). Figure 1 is an activation energy plot showing the activity (total Co turnover number) on a $\log$ scale as a function of the reciprocal temperature. The catalyst activity at the highest temperature $\left(230^{\circ} \mathrm{C}\right)$ is lower than expected based on the irend at the lower temperatures. An activation energy of $89.0 \mathrm{~kJ} / \mathrm{mol}$ was calculated for the lower three temperatures. This compares with $102 \mathrm{~kJ} / \mathrm{mol}$ for catalyst Fe-A-201 reported previously (also at $3 / 1 \mathrm{H}_{2} / \mathrm{CO}$ ratio). The fit is very good for these data considering the reversal of the first two temperature runs $\left(207^{\circ} \mathrm{C}\right.$ and then $200^{\circ} \mathrm{C}$ instead of 200 followed by 207). The extended time on stream before reacting at $230^{\circ} \mathrm{C}(71$ hours compared to 48 preferrec under ideal schedule) may have had an impact on the activity at that temperature. Indeed, longer reaction times deactivated the catalyst by allowing refractory carbon deposits to form which are not easily removed with hydrogen, thus lowering the intrinsic activity.

Figure 2 is a plot of activity (normalized to highest rate) as a function of time. The maximum activity was measured at 10 hours on stream. In the next 40 hours the activity decreased by nearly $70 \%$. Also shown are values of olefin content (of $\mathrm{C}_{3}-\mathrm{C}_{7}$ hydrocarbons) and $\mathrm{CO}_{2}$ production (as fraction of $\mathrm{CO}$ converted to $\mathrm{CO}_{2}$ ). The olefin content increases with time indicating an increase of carbon and/or decrease of hydrogen on the surface. $\mathrm{CO}_{2}$ production decreases with time from 0.53 at the first measurement to 0.41 at the last. 


\section{Table 1. Reaction schedule for catalyst Fe-A-203.}

\begin{tabular}{|c|c|c|c|}
\hline Rxn Set & Reaction conditions & $\begin{array}{l}\mathrm{H}_{2} / \mathrm{CO} / \mathrm{He} \\
\text { flow }(\mathrm{cc} / \mathrm{min}) \\
\end{array}$ & Sample times \\
\hline $3 / 1 \quad(A):$ & $\begin{array}{l}\text { Reduced fresh catalyst at } 400^{\circ} \mathrm{C} \text { for } 1 \\
\text { hr } \\
\mathrm{H} 2 / \mathrm{CO}=3 \text { at } 200 \text { for } 16 \mathrm{hrs} \\
\mathrm{H} 2 / \mathrm{CO}=3 \text { at } 212 \text { for } 33 \mathrm{hrs} \\
\mathrm{H} 2 / \mathrm{CO}=3 \text { at } 227 \text { for } 22 \mathrm{hrs}\end{array}$ & $\begin{array}{l}(30 / 10 / 0) \\
(30 / 10 / 0)\end{array}$ & $\begin{array}{l}\text { Samples taken } a t 27 \text { and } 28 \\
\text { hrs } \\
\text { Samples taken at } 20 \text { and } 21 \\
\text { hrs }\end{array}$ \\
\hline \multicolumn{4}{|c|}{ Re-reduced at $400^{\circ} \mathrm{C}$ for $2 \mathrm{hr}$} \\
\hline $3 / 1(B):$ & $\begin{array}{l}\mathrm{H} 2 / \mathrm{CO}=3 \text { at } 207 \text { for } 38.5 \mathrm{hrs} \\
\mathrm{H} 2 / \mathrm{CO}=3 \text { at } 200 \text { for } 22 \mathrm{hrs} \\
\mathrm{H} 2 / \mathrm{CO}=3 \text { at } 220 \text { for } 11 \mathrm{hrs} \\
\mathrm{H} 2 / \mathrm{CO}=3 \text { at } 230 \text { for } 17 \mathrm{hrs}\end{array}$ & $\begin{array}{l}(30 / \% / 0) \\
(30 / 10 / 0) \\
(30 / 10 / 0) \\
(30 / 10 / 0)\end{array}$ & $\begin{array}{l}\text { Samples taken at } 2.4 \text { and } 25 \\
\text { hrs } \\
\text { Samples taken at } 9 \text { and } 10 \text { hrs } \\
\text { Samples taken at } 9 \text { and } 10 \mathrm{hrs} \\
\text { Samples taken at } 9 \text { and } 10 \mathrm{hrs}\end{array}$ \\
\hline \multicolumn{4}{|c|}{ Re-reduced at $400^{\circ} \mathrm{C}$ for $2 \mathrm{hrs}$} \\
\hline 2/1: & $\begin{array}{l}\mathrm{H} 2 / \mathrm{CO}=2 \text { at } 200 \text { for } 5 \mathrm{hrs} \\
\mathrm{H} 2 / \mathrm{CO}=2 \text { at } 209 \text { for } 12 \mathrm{hrs} \\
\mathrm{H} 2 / \mathrm{CO}=2 \text { at } 220 \text { for } 22 \mathrm{hrs} \\
\mathrm{H} 2 / \mathrm{CO}=2 \text { at } 229 \text { for } 18 \mathrm{hrs}\end{array}$ & $\begin{array}{l}(23 / 10 / 6) \\
(22 / 8 / 13) \\
(20 / 10 / 10) \\
(20 / 10 / 10)\end{array}$ & $\begin{array}{l}\text { Samples taken at } 21 \text { and } 22 \\
\text { hrs } \\
\text { Samples taken at } 8 \text { and } 9 \text { hrs } \\
\text { Samples taken at } 8 \text { and } 9 \text { hrs } \\
\text { Samples taken at } 9 \text { and } 10 \mathrm{hrs}\end{array}$ \\
\hline \multicolumn{4}{|c|}{ Re-reduced at $388^{\circ} \mathrm{C}$ for $16 \mathrm{hrs}$} \\
\hline 1/1: & $\begin{array}{l}\mathrm{H} 2, \mathrm{CO}=1 \text { at } 200 \text { for } 27 \mathrm{hrs} \\
\mathrm{H} 2 / \mathrm{CO}=1 \text { at } 210 \text { for } 21 \mathrm{hrs} \\
\mathrm{H} 2 / \mathrm{CO}=1 \text { at } 220 \text { for } 22 \mathrm{hrs} \\
\mathrm{H} 2 / \mathrm{CO}=1 \text { at } 230 \text { for } 35 \mathrm{hrs}\end{array}$ & $\begin{array}{l}(10 / 11 / 0) \\
(10 / 10 / 0) \\
(10 / 10 / 0) \\
(10 / 10 / 0)\end{array}$ & $\begin{array}{l}\text { Samples taken at } 8 \text { and } 9 \mathrm{hrs} \\
\text { Samples taken at } 6 \text { and } 7 \mathrm{hrs} \\
\text { Samples taken at } 6 \text { and } 7 \mathrm{hrs} \\
\text { Samples taken at } 9 \text { and } 10 \mathrm{hrs}\end{array}$ \\
\hline \multicolumn{4}{|c|}{ Re-reduced at $404^{\circ} \mathrm{C}$ for $12 \mathrm{hrs}$} \\
\hline $\begin{array}{l}\text { 1.5/1: } \\
\text { (Deactiva }\end{array}$ & $\begin{array}{l}\mathrm{H} 2 / \mathrm{CO}=1.5 \text { at } 2.30 \text { for } 67 \mathrm{hrs} \\
\text { (tion) }\end{array}$ & $(20 / 13 / 0)$ & $\begin{array}{l}\text { Samples taken at } 6,10,14, \\
17,21,25,29,32,36,40 \\
43,47,51,55,58,62 \mathrm{hrs}\end{array}$ \\
\hline
\end{tabular}




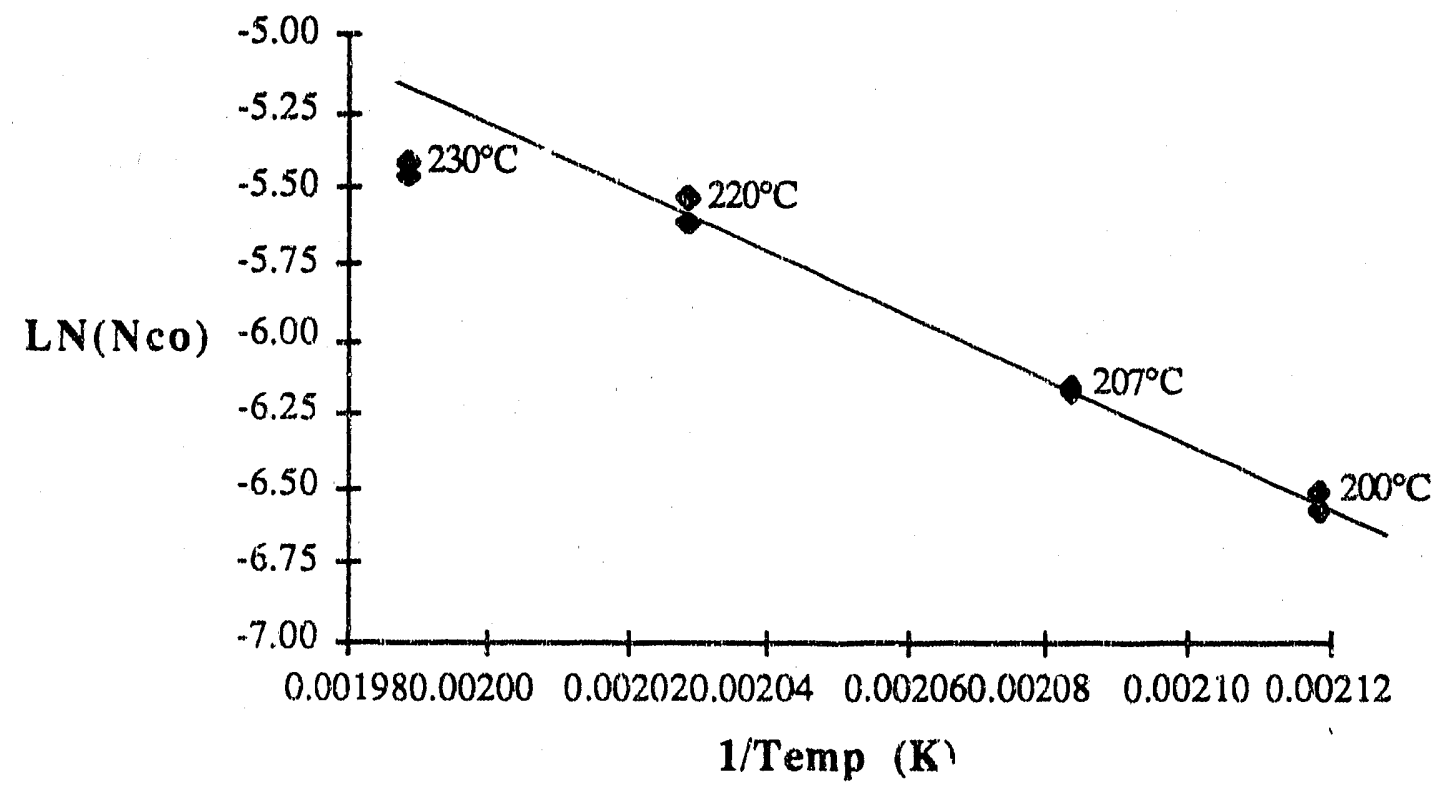

Figure 1. Activation energy plot at $3 / 1 \mathrm{H}_{2} / \mathrm{CO}$ ratio.

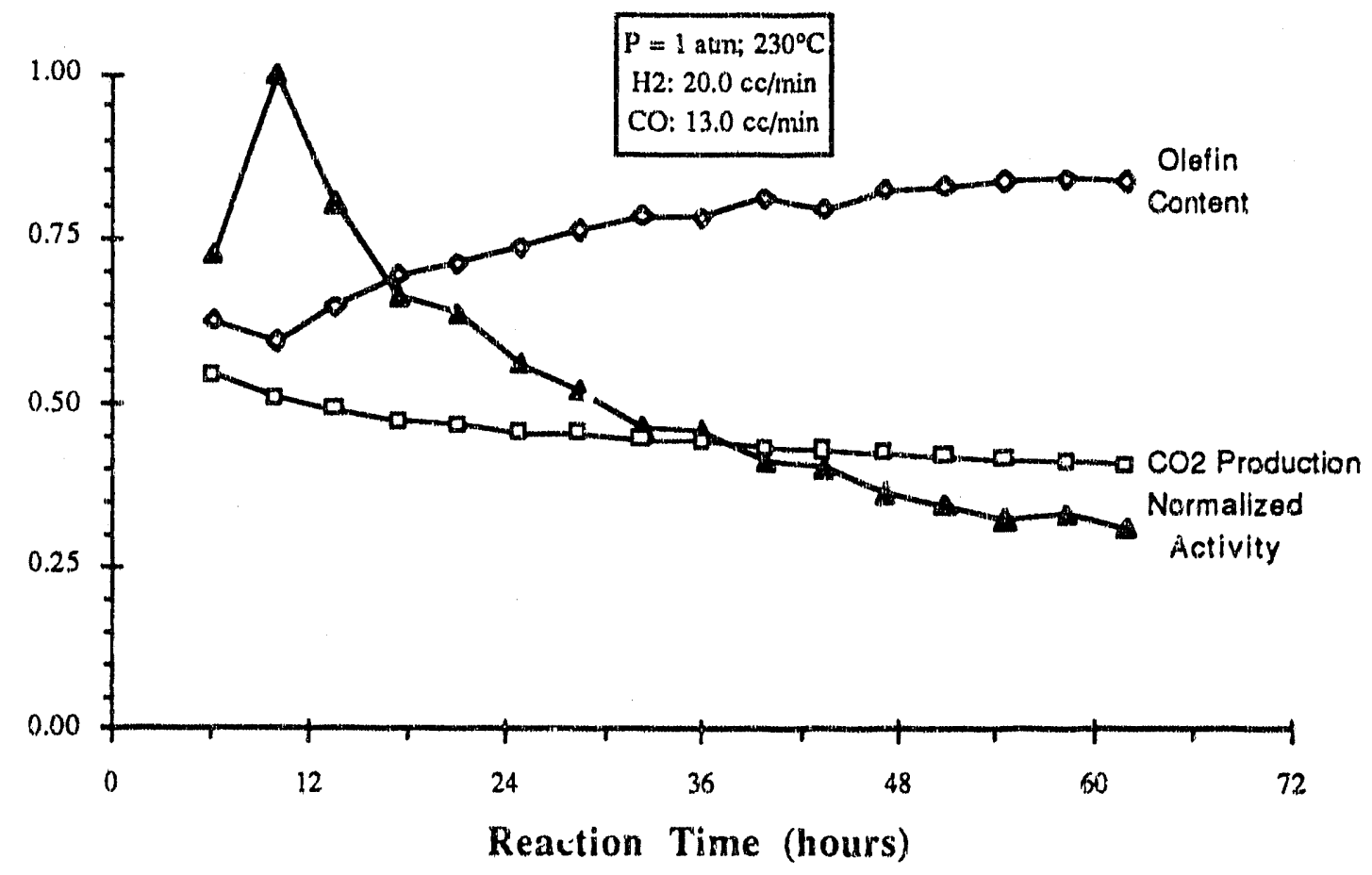

Figure 2. Fe-A-203 deactivation plot.

Results for Fe-A-204. This catalyst was to be used to supplement Fe-A-203 at $\mathrm{H}_{2} / \mathrm{CO}$ ratios of $2 / 4$ and $1 / 1$. However, after reacting at $200-220^{\circ} \mathrm{C}$ for 48 hours and not being 
able to obtain steady $\mathrm{CO}$ and $\mathrm{He}$ flows the reaction runs were cancelled. The catalyst was then rereduced and one chemisorption was then performed on it which resulted in a $\mathrm{H}_{2}$ uptake of 29.1

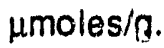

Results for Fe-A-205. Runs were made for this catalyst sample at $\mathrm{H}_{2} / \mathrm{CO} / \mathrm{He}$ ratios of $3 / 1 / 0,2 / 1 / 1,1 / 1 / 0$ and $1 / 1 / 2$ with the total flow kept constant at $40 \mathrm{cc} / \mathrm{min}$ for each. At each set of flows reaction data were obtained at 200, 210, 220 and $23{ }^{\circ} \mathrm{C}$. Figure 3 shows the activity data (total $\mathrm{CC}$ turnover number) for each set of gas flows and temperatures. The first and third set of data appear to have t'e expected trend-activity increases with increasing temperature. Howeve', the second set did not exhibit those same characteristics. Activity increased for the lower three temperatures but decreased at the highest temperature $\left(230^{\circ} \mathrm{C}\right)$. This drop may be due to deactivation as the samples were taken at 22 and $23 \mathrm{hrs}$ on stream rather than 10 12. The last sat $(1 / 1 / 2)$ was incomplete due to a crack that developed in the ten-port sampling valve in the gas chromatugraph. Because of these inconsistencies the second and fourth sets $\left(\mathrm{H}_{2} / \mathrm{CO} / \mathrm{He}\right.$ ratios of $2 / 1 / 1$ and $\left.1 / 1 / 2\right)$ will be rarione. One of the temperatures at the $1 / 1 / 0$ ratio will also be redone to measure the reproducibility of the data.

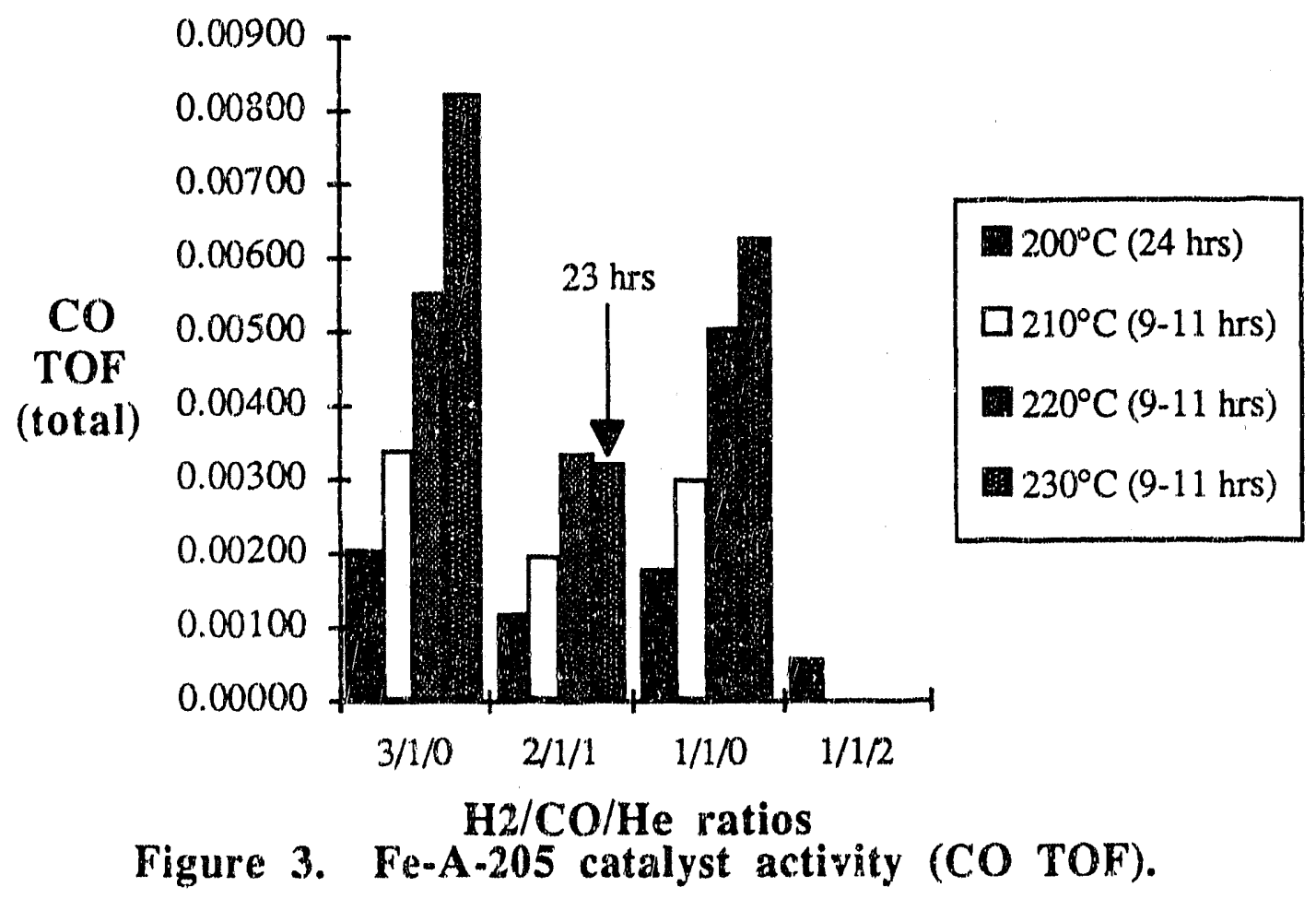


The activity of the initial fresh catalysts was followed from about 1 to $30 \mathrm{hrs}$ on stream for the $3 / 1 / 0$ and $2 / 1 / 1$ ratios at $200^{\circ} \mathrm{C}$. Figures 4 and 5 show the catalyst activity in termis of total $\mathrm{CO}$ converted and of hydrocarbons $(\mathrm{HC})$ produced. Both figures exhibit similar characieristics but the deactivation effects are mor pronounced in the $3 / 1 / 0$ run, that is, the total CO consumption decreases initially somewhat and then increases io a constant value after about 20 hours. The reason for this behavior is evident when the total $\mathrm{CO}$ consumption is broken down into the $\mathrm{CO}_{2}$ and $\mathrm{HC}$ components. Hydrocarbon production is seen to rise until it reaches a constant value after 20 hours. The drop in total $\mathrm{CO}$ consumption the, 1 must be due to changes in $\mathrm{CO}_{2}$ production. Indeed, the $\mathrm{CO}_{2}$ production (shown as fraction of $\mathrm{CO}$ converted to $\mathrm{CO}_{2}$ ) decreases from initial values of $85 \%(3 / 1 / 0)$ and $65 \%(2 / 1 / 1)$ to about $30 \%$ in both cases. Initially, the reaction to produce $\mathrm{CO}_{2}$ accounts for most of the $\mathrm{CO}$ consurned but as the catalyst becomes more covered with carbon the reaction of $\mathrm{CO}$ to hydrocarbons becomes the dominating reaction.

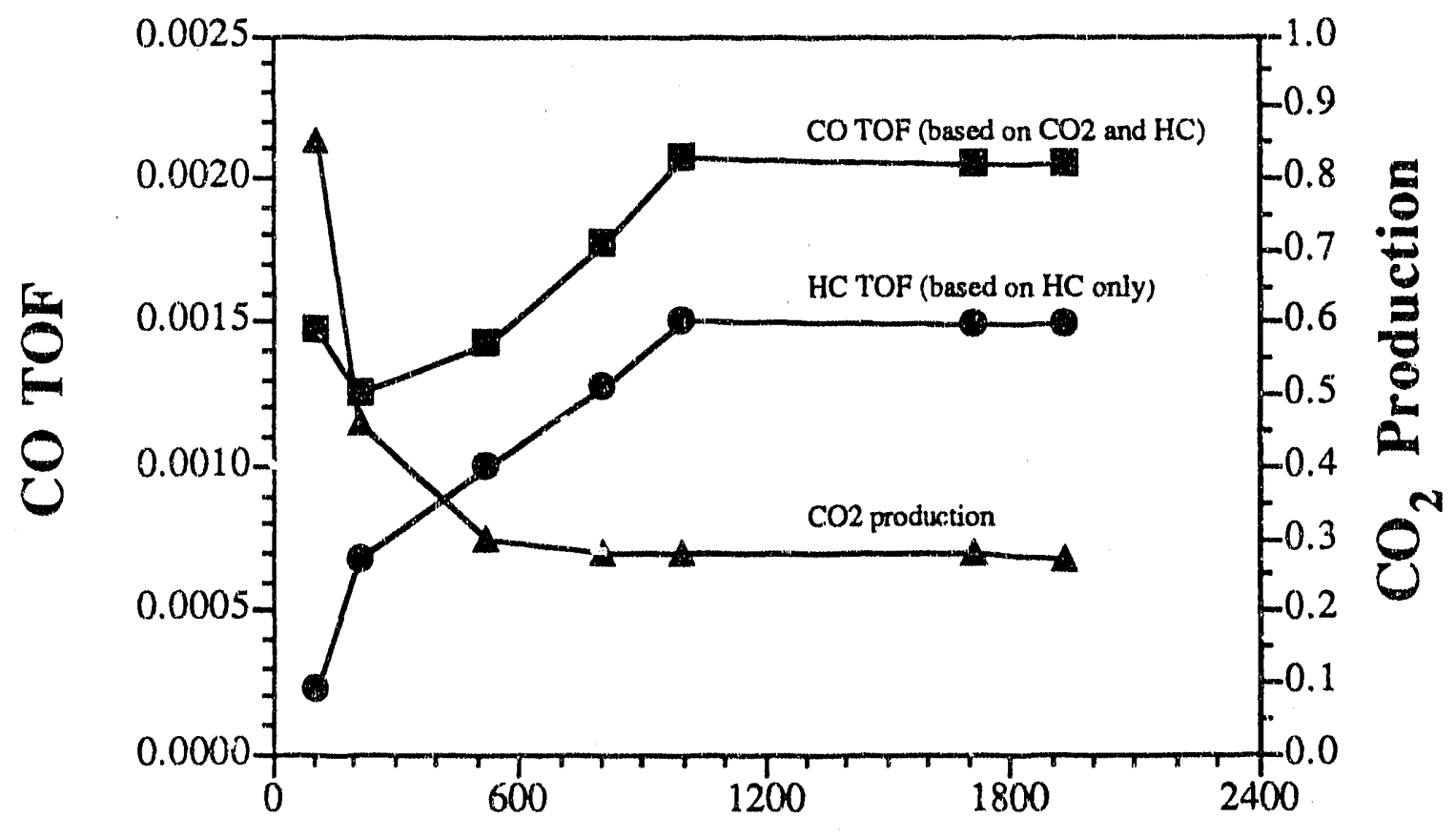

Time (min)

Figure 4. Catalyst activity as a function of total $\mathrm{CO}$ consumption and $\mathrm{HC}$ production. $\left(200^{\circ} \mathrm{C}, 3 / 1 / 0 \mathrm{H}_{2} / \mathrm{CO} / \mathrm{He}\right.$ ratio) 


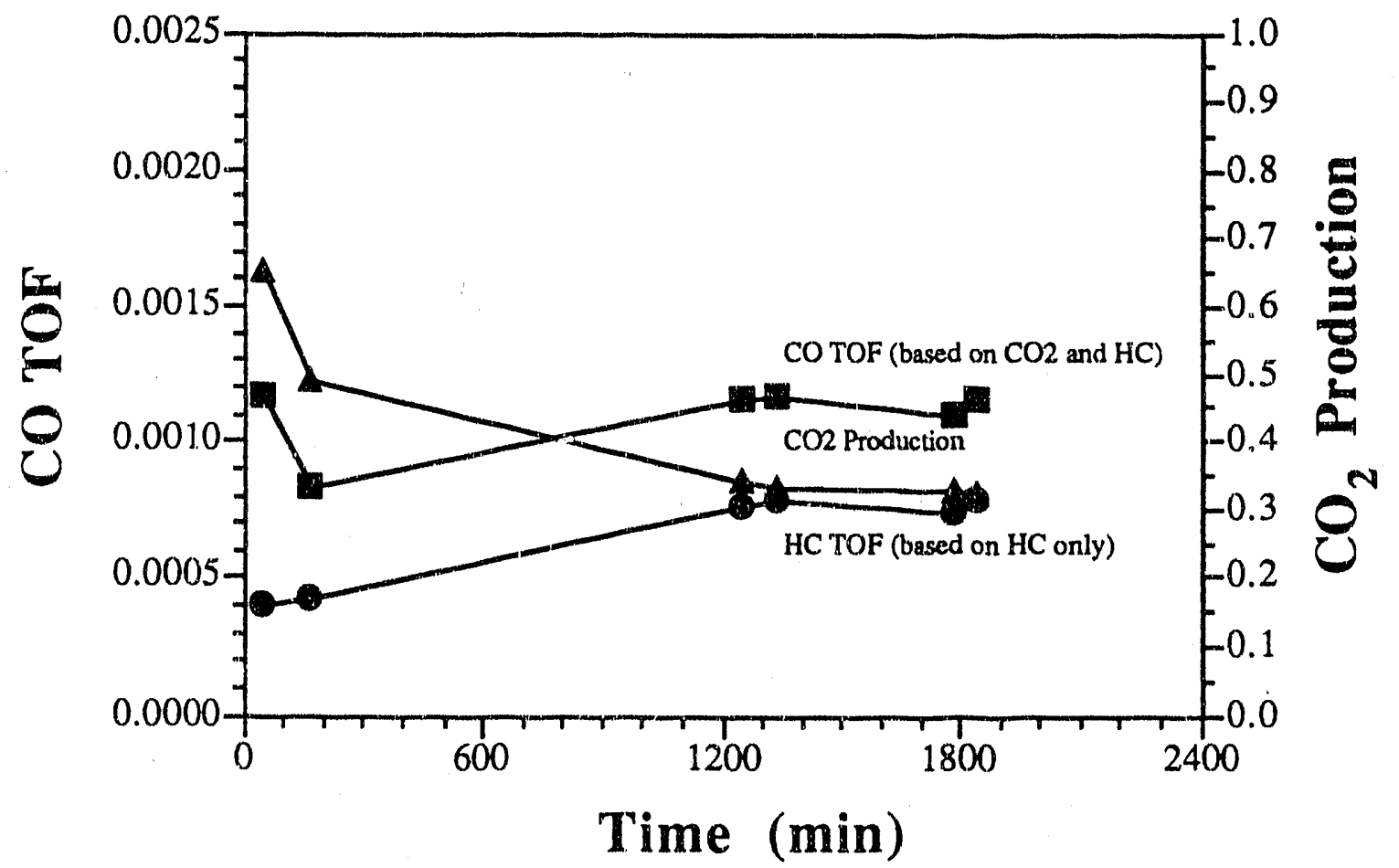

Figure 5. Catalyst activity as a function of total CO consumption and $\mathrm{HC}$ production. $\left(200^{\circ} \mathrm{C}, 2 / 1 / 1 \mathrm{H}_{2} / \mathrm{CO} / \mathrm{He}\right.$ ratio)

Activation energies were calculated from the activity data by plotting the natural logarithm of the $\mathrm{CO}$ turnover number agairst the reciprocal temperature (Arrhenius plot). Figure 6 shows the data and the regression parameters. The lowest three temperatures were used to calculate the activation energies since the effect of deactivation appears to be significant at $230^{\circ} \mathrm{C}$ as seen by activities that fall below the regression lines. The values of 102 and $107 \mathrm{~kJ} / \mathrm{mol}$ are consistent with previous values of $102 \mathrm{~kJ} / \mathrm{mol}$ for $\mathrm{Fe}-\mathrm{A}-201$ (at $\left.3 / 1 / 0 \mathrm{H}_{2} / \mathrm{CO} / \mathrm{He}\right)$.

From this new set of data it is possible to calculate reaction orders ( $x$ and $y$ ) in the reaction rate expression $-r \mathrm{CO}=k\left(\mathrm{PCO}^{x}\left(\mathrm{PH}_{2}\right) y\right.$. To calculate $x$, for example, requires that data be obtained at a constant partial pressure of $\mathrm{H}_{2}$ at two or more pressures of $\mathrm{CO}$. Taking the logarithm of both sides of the rate expression and lumping all constants together gives an expression of the form $C=\times \operatorname{LN}(P C O)$ where $C$ is a constant. A plot of $C$ versus $L N(P C O)$ yields a regression slope equal to $x$. Figures 7 and 8 show the plots from which the coefticients were calculated. The rate expression becomes $-r \mathrm{CO}=k\left(\mathrm{P}_{\mathrm{CO}}\right)^{0.60}\left(\mathrm{P}_{\mathrm{H}}\right)^{1.36}$ with the values obtained from these plots. For the conditions of these experiments this indicates that the rate is more dependent upon tive hydrogen partial pressure than the co partial pressure but that increases in either one will increase the rate. Extrapolating to conditions outside the bounds of these experiments may result in incorrect conclusions. 


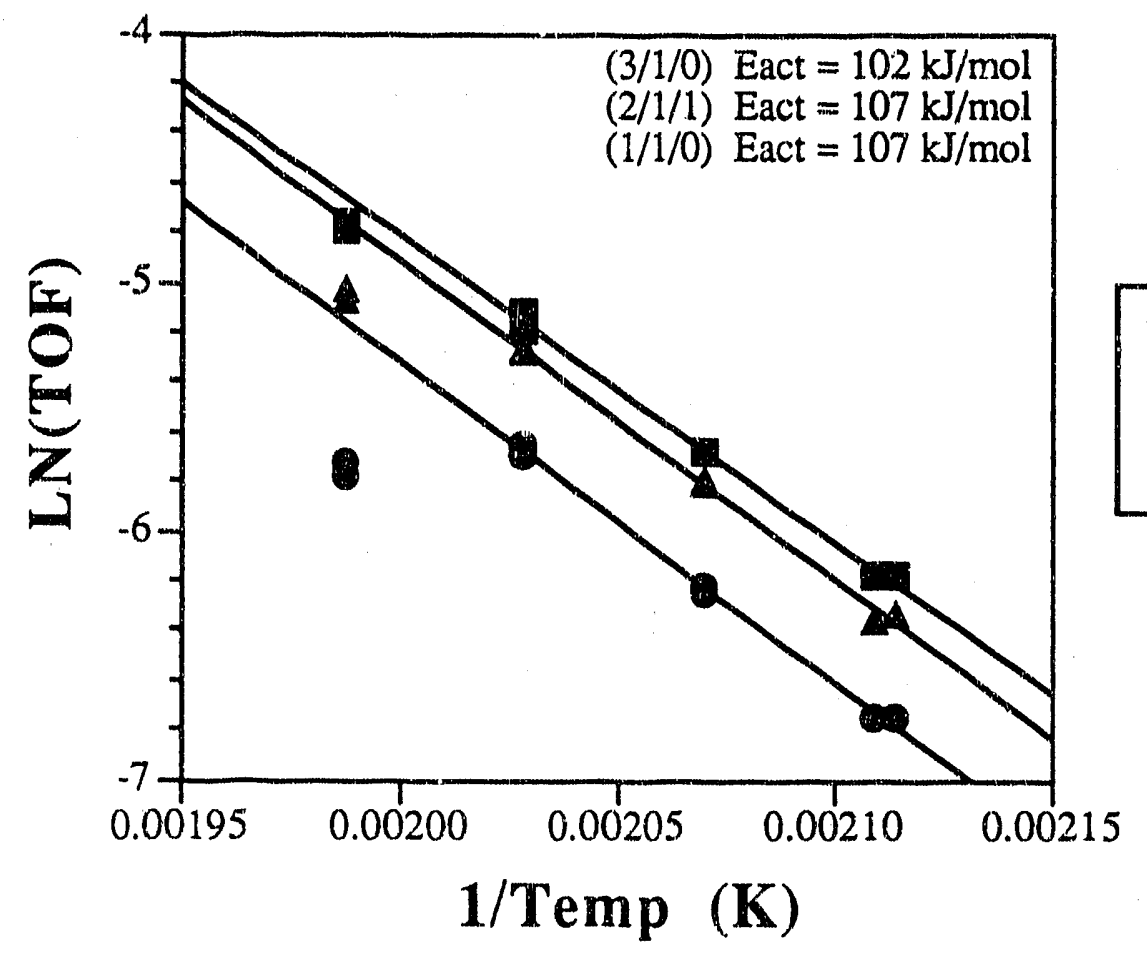

3, ${ }^{\prime} 1 / 0$ ratio

- $2 / 1 / 1$ ratio

A $1 / 1 / 0$ ratio

Figure 6. Arrhenius plots for Fe-A-205.

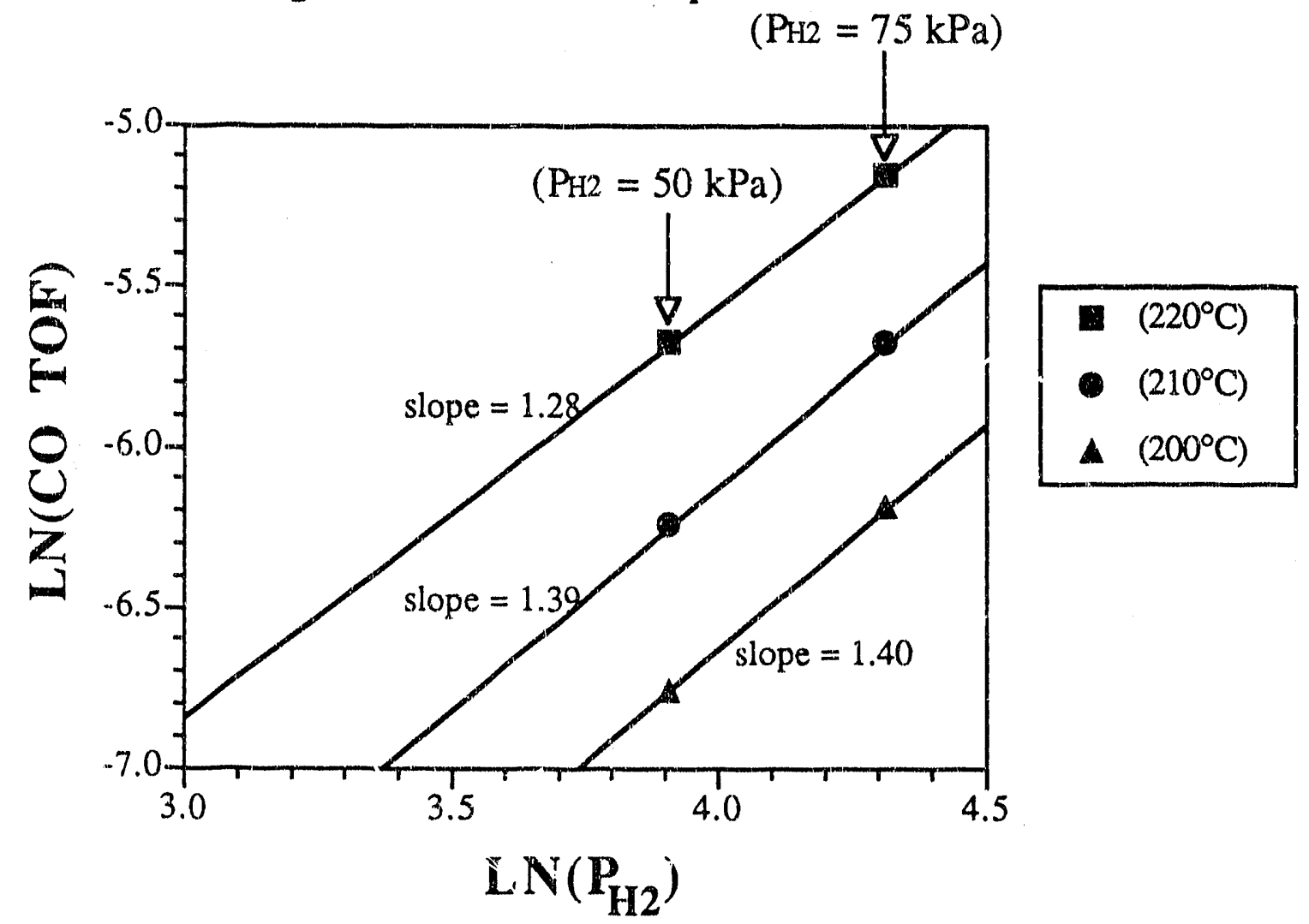

Figure 7. Reaction orders for coñstant $\mathrm{P}_{\mathrm{CO}}(25 \mathrm{kPa})$ at $200-220^{\circ} \mathrm{C}$. 


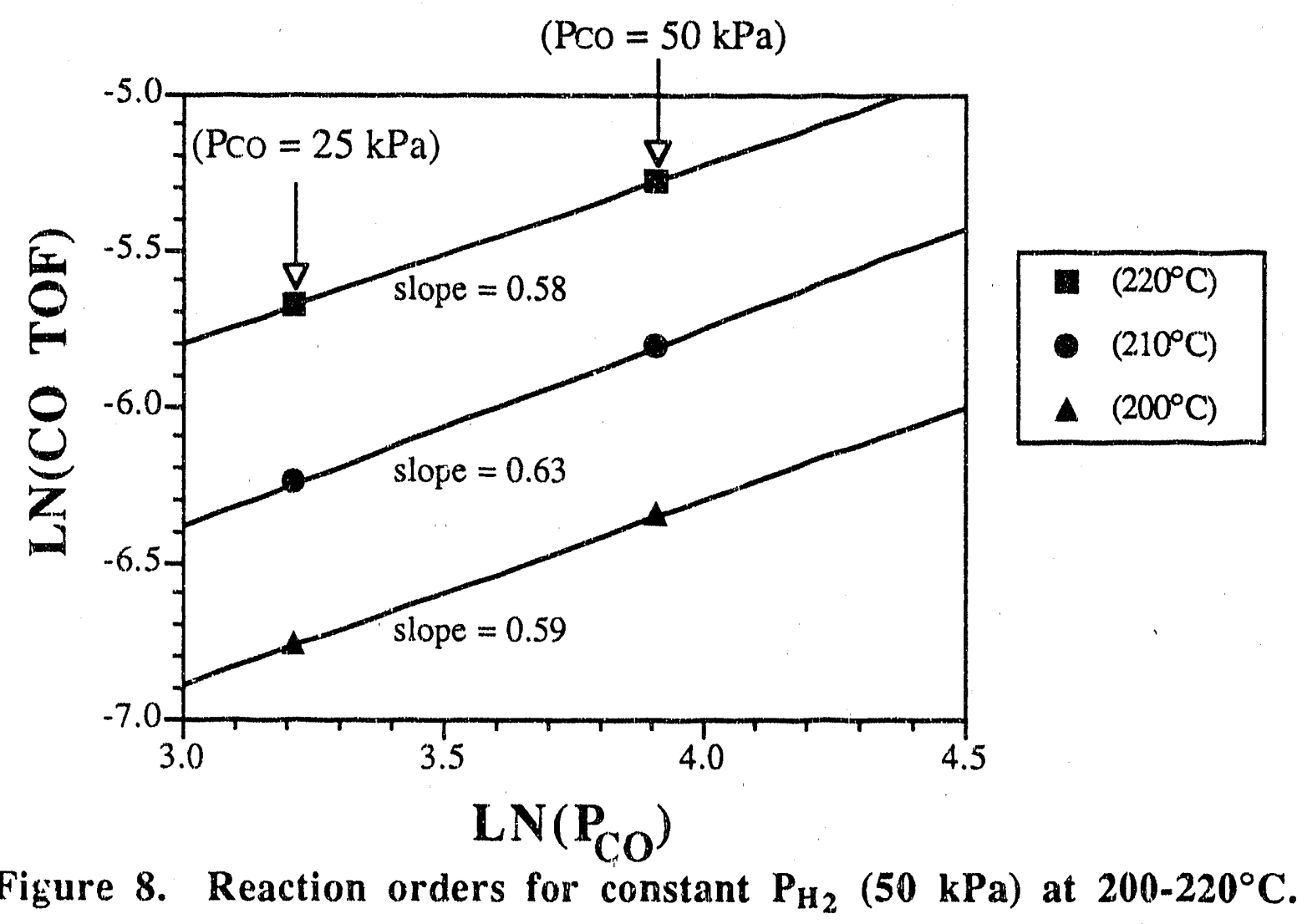

B. Task 2: Study of Carbon Reactivities and Types

No experiments are scheduled for this task until Fall 1990. The research assistants working on this project are presently familiarizing themselves with the literature dealing with deactivation by carbon.

C. Task 3: Mathematical Modeling of Catalyst Deactlvation by Carbon This task is scheduled to begin in the Winter 1991.

D. Task 4: Technical Communication and Miscellaneous Accomplishments

The Principal Irivestigator, Calvin . i. Bartholomew, his associate William C. Hecker, and several students attended Advarices in Catalytic Chemistry held October 1-6 at Snowbird, Utah. The PI presented an invited paper dealing with "Effects of Structure on CO Hydrogenation on Alumina-supported Cobalt and Iron." 


\section{REFERENCES}

1 a. Dry, M.E., "The Fischer-Tropsch Synthesis," in Catalysis Science and Technology, J.R. Anderson and M. Boudart, editors, Springer-Verlag, New York 1981, pp. 159-256.

b. Dry, M.E., Private Communication, Synfuels Workshop, Aug., 1985.

2. Atwood, H.J.E., and Bennett, C.O., Ind. Eng. Chem. Process Des. Dev., 18, 163 (1979).

3. Huff, G.A., Jr., and Satterfield, C.N., "Kinetics of the Fischer-Tropsch Synthesis on Reduced, Fused Magnetite," Presented at the Annual AlChE Meeting, Los Angeles, 1982.

4. Dictor, R.A. and Bell, A.T., "Fischer-Tropsch Synthesis over Reduced and Urireduced Iron Oxide Catalysts," J. Catal. 97, 121 (1986).

5. Sughrue, E.L., "Kinetic and Carbon Deactivation Studies of Nickel Catalysts," Ph.D. dissertation, Brigham Young University, 1980.

6. Jarvi, G.A., Mayo, K.B., and Bartholomew, C.H., "Monolithic-Supported Catalysts; I. Methanation Activity Relative to Pellet Catalysts," Chem. Eng. Commun., 4, 325 (1980).

7. Bowman, R.M., and Bartholomew, C.H., "Deactivation by Carbon of Ru/Al2O3 During CO Hydrogenation," Appl. Catal. 7, 179 (1983).

8. Barthoiomew, C.H., Weatherbee, G.D., and Jarvi, G.A., Chem. Eng. Commun., 5, 125 (1980).

9. Rameswaren, M. and Bartholomew, C.H., "Physical and Chemical Properties of $\mathrm{Fe}(\mathrm{Co}) 5 / \mathrm{Alumina}$ CO Hydrogenation Catalysts," presented at the 192nd Meeting of the American Chemical Society, Anaheim, Sedt. 7-12, 1986

10. Rameswaren, M., "A Study of CO Hydrogenation on Carbonyl-Derived and ConventionallyPrepared Fe/Alumina Catalysts," Ph.D. Dissertation, Brigham Young University, Provo, Utah, Dec. 1986.

11. Reuel, R.C., and Bartholomew, C.H., "The Stoichiometries of $\mathrm{H}_{2}$ and $\mathrm{CO}$ adsorptions on Cobalt: Effects of Support and Preparation," J. Catal, 85, 63 (1986).

12. Rankin, J.L., and Bartholomew, C.H., "Effects of Support on the Adsorption and CO Hydrogenation Activity/Selectivity Properties of Iron," paper in preparation, 1987.

13. Sughrue, E.L., and Bartholomew, C.H., "Kinetics of CO Methanation of Nickel Monolithic Catalysts," Appl. Catal., 2, 239 (1983).

14. Levenspiel, O., "Chemical Reaction Engineering," John Wiley, New York, 1972.

15. Bartholomew, C.H., "Investigation of Sulfur-Tolerant Catalysts for Selective Synthesis of Hydrocarbon Liquids from Coal-Derived Gases," Annual Report to DOE, DOE-ET-14809-4, October 10, 1980.

16. Duncan, T.M., Winslow, P., and Bell, J. Catal., 93, 1 (1985).

17. Zowtiak, J.M., "Metal-Support Interactions in Cobalt Catalysts: Their Effects on Adsorption/Desorption Kinetics of Hydrogen and Carbon Monoxide," M.S. Thesis, Brigham Young University, 1983.

18. Zowtiak, J.M., and Bartholomew, C.H., "The Kinetics of $\mathrm{H}_{2}$ Adsorption and Desorption from Cobalt and the Effects of Support Thereon," J. Catal., 83, 107 (1983). 
19. Weatherbee, G.D., and Bartholomew, C.H., "Effects of Support on Hydrogen Adsorption/Desorption Kinetics of Nickel," J. Catal., 87, 55-65 (1984).

20. Gorte, R.J., J. Catal., 85, 143 (1984).

21. Rieck, J.S., and Bell, A.T., J. Catal., 85, 143 (1984).

i. 2. McCarty, J.G., and Wise, H., J. Catal., 57, 406 (1979).

23. Dyer, D.J., "Iron Fischer.Tropsch Catalysts: Surface Synthesis at High Pressure," Symposium of the New Surface Science in Catalysis, American Chemical Society, Philadeiphia Meeting, August 26-31, 1984.

24. Bartholomew, C.H., "Carbon Deposition in Steam Reforming and Methanation," Catal. Rev. -Sci. Eng., 24, 7 (1982).

25. Erekson, R.J., Sughrue, E.L., and Bartholomew, C.H., Fuel Proc. Technol., 5, 91 (1981).

26. Gardner, D.C., and Bartholomew, C.H., Ind. Eng. Chem. Prod. Res. Dev. 20, 80 (1981).

27. Amelse, J.A., Butt, J.B., and Schwartz, L.H., J. Phvs. Chem., 82, 558 (1978).

28. Raupp, G.B., and Delgass, W.M., J. Catal., 58, 348 (1979).

29. LO, C., Rao, K.R.P.M., Mulay, L.N., Rao, V.U.S., Obermeyer, R.T., and Cormley, R.J., Advances in Chem. Series, 194, 573-588 (1981).

30. Brewster, 3.S., and Bartholomew, C.H., "Performance Prediction Methods for Methanation: Monolith and Fluidized Bed Reactors," Submitted to the General Electric Company, ARSD, September 30, 1981.

31. Brewster, B.S. Suchrue, E.L., and Bartholomew, C.H., in preparation, 1986.

32. Bartholomew, C.H., "Catalyst Deactivation: Causes, Mechanisms, and Treatment," Chemicai Engineering, 91, (23), 96 (1984).

33. Smith, J.M., Chemical Engineering Kinetics, 3rd Ed., McGraw-Hill, 1981.

34. Rankin, J.L., and Bartholomew, C.H., "A Matherriatical Model of Activity/Selectivity of FischerTropsch Catalysts," paper in preparation, 1986.

35. Rabo, J.A., Risch, A.P., and Putsma, M.D., J. Catal., 53, 295 (1978).

36. Sachtler, J.W.A., Kool, J.M., and Ponec, V., J. Catal., 56, 284 (1979).

37. Goodman, D.W., Kelley R.D., Madey, T.E., and White J.M., Surf. Sci. Lett. 90, 201 (1979).

38. Ponec, V., "Some, Aspects of the Mechanism of the Methanation and Fischer-Tropsch Synthesis," Catai. Rev. Sci. Eng., 18, 151 (1978).

39. Kibby, C.L., and Kobylinski, T.P., "Models of Product Distribution in Fischer-Tropsch Synthesis," Symposium in Advances in Synthetic Fuels, Presented before the ACS Division of Petroleum Chemistry, Miami Beach, September, 10-15, 1978.

40. Bell, A.T., Catal. Rev.-Sci. Eng., 23, 203 (4981).

41. Bileon, P., and Sachtler, W.M.J., Adv. Catal., 30, 165 (1981). 
42. Grenoble, D.C., Estadt, M.M. and Ollis, D.F., "The Chemistry und Catalysis of the Water Gas Shift Reaction," J. Catal., 67, 90-102 (1981).

43. a. Bennion, D.N., private communication, 1983.

b. Newman, 4., Electrochemical Systems, Prentice-Hall, Englewood Cliffs, N.J., 1973.

44. Berty, J.M., "Testing Commercial Catalysts in Recycle Reactors," Catal. Rev. - Sci. Eng. 20, 75 (1979).

45. Bartholomew, C.H., "Deactivation by Carbon of Iron Catalysts for indirect Liquifaction," DOE-PC5033-1, Jan. 7, 1987.

46. Bartholomew, C.H. and Bayles, F.M., "Macintosh Process Control," Macintosh Journal, 1 (5), 10 (1987).

47. Bartholomew, C.H., "Deactivation by Carbon of Iron Catalysts for Indirect Liquefaction," Annual Report to DOE, DOE-PC-90533-4, Nov. 15, 1987. 


\section{APPENDIX \\ REPORT DISTRIBUTION LIST}

Internal (Department of Chemical Engineering):

Chemical Engineering Faculty (Circulate)

Dr. William C. Hecker

Mr. Scott Eliason

External

A. Technical Project Officer (1 copy): Mr. Rober t Dolence

U.S. Department of Energy

Pittsburgh Energy Technology Center

P. O. Box 10940, MS 922-206

Pittsburgh, PA 15236

D. Patent Group (1 copy) ${ }^{\mathrm{a}}$

U.S. Department of Energy Office of Patent Council Chicago Operations Office 9800 South Cass Avenue Argonne, IL 60439

B. Acquisition (1 copy)

Mr. Keith R. Miles

Acquisition \& Assistance Div.

U.S. Department of Energy

Pittsburgh Energy Tech. Center

P. O. Box 10940

Pittsburgh, PA 15236

E. PETC Administration (2 copies)

Ms. Marilyn Keane

U.S. Department of Energy

Pittsburgh Energy Tech. Center

P. O. Box 10940, MS $922 \mathrm{H}$

Pittsburgh, PA 15236

C. Technical Infermation Center

U.S. DOE

Office of Science and Technical Information

P. O. Box 62

Oak Ridge, TN 37380

F. Washingten (1 copy)

Mr. Paul C. Scott

U.S. Department of Energy

FE - T4, E-161, GTN

Washington, D.C. 20545

aplus clearance form

bunbound copy 


\begin{tabular}{|c|c|c|}
\hline $\begin{array}{l}\text { WIBLIOGKAPHIC DATA } \\
\text { SHEET }\end{array}$ & \begin{tabular}{|l|l|} 
1. Meport No. & 2. \\
DOE-PC-90533-13 &
\end{tabular} & 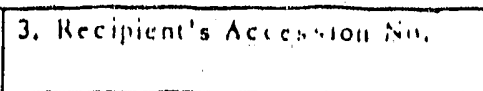 \\
\hline \multirow{2}{*}{\multicolumn{2}{|c|}{$\begin{array}{l}\text { 4. Tirle and Subricle } \\
\text { DEACTIVATION BY CARBCIN OF IRON CATALYSTS FOR INDIRECT } \\
\text { LIQUEFACTION }\end{array}$}} & $\begin{array}{l}\text { 5. Rrpout 1) ale } \\
10 / 11 / 90\end{array}$ \\
\hline & & 6. \\
\hline \multicolumn{2}{|c|}{$\begin{array}{l}\text { 7. Author(s) } \\
\text { Calvin H. Bartholomew }\end{array}$} & $\begin{array}{l}\text { 8. Porforming Organization Rept. } \\
\text { No. }\end{array}$ \\
\hline \multicolumn{2}{|c|}{ 9. Performing Organization Name und Addess } & 10. Project/Task/H'ork Unit No. \\
\hline \multicolumn{2}{|c|}{$\begin{array}{l}\text { Brigham Young University Catalys is Laboratory } \\
350 \text { CB } \\
\text { Provo, UT } 84602\end{array}$} & $\begin{array}{l}\text { 11. Contract/Grani No. } \\
\text { DE-FG22-86PC90533 }\end{array}$ \\
\hline \multirow{2}{*}{\multicolumn{2}{|c|}{$\begin{array}{l}\text { 12. Sponsoring Organizacion Name and Address } \\
\text { Brigham Young University } \\
\text { Provo, UT } 84602\end{array}$}} & $\begin{array}{l}\text { 13. Type of Reporr \& Period } \\
\text { Covcred } \\
\text { Quarterly }\end{array}$ \\
\hline & & 14. $9 / 16 / 89$ to $12 / 15 / 89$ \\
\hline
\end{tabular}

15. Supplemeniary Noces

16. Abstrncis

During the thirteenth quarter design of software for a computer-automated reactor system to be used in the kinetic and deactivation studies was continued. Further progress was made towards the completion of the control language, control routines, and software for operating this system. Progress was also made on the testing of the system hardware and software. $H_{2}$ chemisorption capacities and activity selectivity data were also measured for three iron catalysts promoted with $1 \%$ alumina. The PI, one associate and several students attended Advances in Catalytic Chemistry IV held October 1-6 at Snowbird, Utah were the PI presented a paper.

17. Key Words and Document Analysis, 170. Descriptors

Co Hydrogenation, Fe

Deactivation, FT Catalysts

FT Synthesis, Fe

17b. Identificrs/Open-Ended Terms

17c. COSAT1 Field/Group

18. Availability Seacement

\begin{tabular}{|c|c|}
\hline 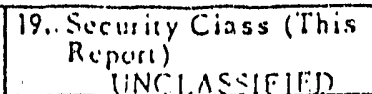 & $\begin{array}{l}\text { 21. Nu. u! Hages } \\
20\end{array}$ \\
\hline 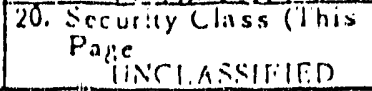 & 22. Price \\
\hline
\end{tabular}



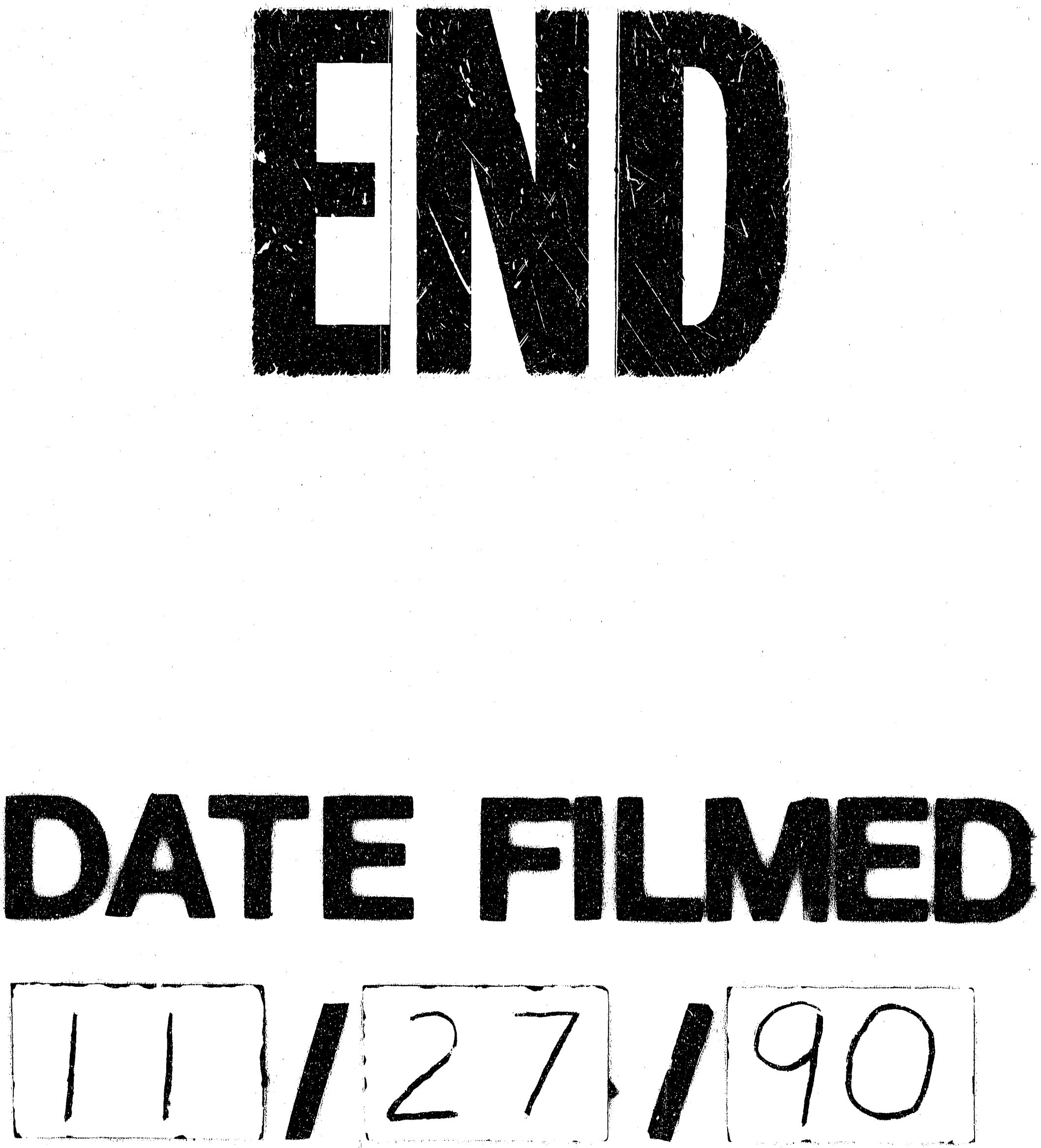
